\title{
Lise Öğrencilerinde Gelecek Beklentisi ve Öz Güven İlişkisi
}

\section{Hüseyin ŞİMŞEK ${ }^{* *}$, Menderes ÜNAL ${ }^{* * *}$, Şeyma ERBAY MERMER ${ }^{* * * *}$ ve Dildar ÖZASLAN ${ }^{* * * *}$}

Öz: Bu araştırma lise öğrencilerinin çeşitli boyutlardaki gelecek beklentileri ile öz güvenleri arasındaki ilişkiyi belirlemek amacıyla yapılmıştır. Araştırmanın örneklemi, Kırşehir merkez ilçedeki en yaygın lise türlerinin 11. sınıfında öğrenim gören seçkisiz yolla belirlenen 303 öğrenciden oluşmaktadır. Araştırmanın verileri Gelecek Beklentisi Ölçeği ve Öz güven Ölçeği ile toplanmıştır. Araştırma sonuçlarından elde edilen bulgular doğrultusunda cinsiyet değişkeninin öz güven açısından kayda değer bir değişken olmadığı ancak gelecek beklentisi açısından anlamlı bir fark oluşturduğu görülmüştür. Diğer taraftan üniversite mezunu olmayan annelerin çocukların gelecek beklentisinde daha etkili oldukları; öğrencilerin okul bırakma eğilimlerine göre gelecek beklentisi ve öz güven düzeylerinde farklılık oluşturmamaktadır. Öğrencilerin akademik başarı ortalamaları ile öz güven düzeyleri arasında istatistiksel bir farklılık görülmezken akademik başarı düzeyi pekiyi olan öğrenciler ile başarı düzeyleri orta ve iyi olan öğrencilerinin gelecek beklentisi puanları karşılaştırıldığında, akademik başarı düzeyleri pekiyi olan öğrenciler aleyhine anlamlı farklılıklar olduğu ortaya çıkmıştır. Öğrencilerin ailelerinin sosyo-ekonomik düzeylerinin öz güven düzeyleri üzerinde anlamlı farklılık oluşturmadığı, gelecek beklentisi düzeylerinde ise istatistiksel olarak anlamlı farklılığa yol açtığı gözlenmiştir. Ayrıca öğrencilerin öz güven düzeyleri ile gelecek beklentisi arasında anlamlı bir ilişkinin olmadığı sonucuna ulaşılmıştır.

Anahtar Sözcükler: Lise öğrencileri, gelecek beklentisi, öz güven, ortaöğretim

\footnotetext{
* Bu çalışma II. Uluslararası Sosyal Bilimler Sempozyumu'nda (2017) sözlü bildiri olarak sunulmuş ve bildiri özet kitabında basılmıştır.

** Prof. Dr., Kırşehir Ahi Evran Üniversitesi, Eğitim Programları ve Öğretim Anabilim Dalı, Eğitim Bilimleri Bölümü. husimsek@hotmail.com, https://orcid.org/0000-0001-7455-3706

*** Doç. Dr., Kırşehir Ahi Evran Üniversitesi, Eğitim Bilimleri Bölümü, Eğitim Programları ve Öğretim Anabilim Dalı. menderesunal@gmail.com, https://orcid.org/0000-0001-9439-3308

**** Öğr. Gör., Bilecik Şeyh Edebali Üniversitesi, Rektörlük, sey.erbay@gmail.com, https://orcid.org/0000-0002-7747-9545

***** Arş. Gör., Kırşehir Ahi Evran Üniversitesi, Eğitim Bilimleri Bölümü, Eğitim Programları ve Öğretim Anabilim Dalı, dildarozaslan@hotmail.com, https://orcid.org/0000-0002-9733-2276
} 


\section{The Relationship between Future Expectation and Self Confidence of High School}

\section{Students}

Abstract: This research was carried out in order to determine the relationship between the expectations and self-confidences of high school students in Kırşehir. The sample of the study consists of 303 students who were randomly selected from $11^{\text {th }}$ grade high school students in Kirşehir. The data of the study were obtained by employing Future Expectation Scale and Self Confidence Scale. In the light of the findings, gender has been found not an important variable in terms of self-confidence, but the students' gender and mothers’ literacy levels have made a significant difference in the expectation. It was seen no difference in both selfconfidence and future expectation levels according to the type of school, housing and school dropout tendency. It has also been concluded that students with high school satisfaction levels have low self-confidence and high expectations for the future. There is a significant difference between the students with high academic achievement level and the future expectancy scores of the students who has medium or fairly well achievement. The difference has been found in favour of second group. In addition, no relationship was found between students' selfconfidence levels and future expectations.

Keywords: High School students, future expectation, self-confidence, secondary education

\section{Giriş}

İnsan yaşamı, beklentiler üzerine şekillenmektedir. Beklenti kavramını, “gerçekleşmesi beklenen şey” ya da "bireyin kendisinden beklenenler konusundaki öngörüsü” olarak tanımlanmıştır (Türk Dil Kurumu [TDK], 2011). Bir başka tanıma göre beklenti, önceki deneyimlerden yola çıkarak gelecekte ne olabileceği konusunda çıkarımlarda bulunmaktır (Tatar, 2005). Bu anlamda geçmiş deneyimler ile gelecek beklentisi arasında güçlü bir ilişki bulunmaktadır.

Başarı ile beklenti arasında nasıl bir ilişki olduğu sorgulanmaktadır. Bazı araştırmalarda beklenti düzeyinin insan davranışlarını doğrudan etkilediğine işaret edilmiştir (Bandura, 1997; Taylor ve Brown, 1988). Bunun temel nedeni yüksek başarı beklentisinin, bireyde güçlü bir performans oluşturmasıdır. Güçlü performans ise daha yüksek başarı beklentisine yol açmaktadır. Bu nedenle beklenti hem bireyin geçmiş deneyimleri hem de performans geçmişi hakkında önemli bilgiler vermektedir (Bandura, 1977; Mischel, Cantor, 
ve Feldman, 1996). Yüksek beklenti, yüksek performans1 getirmekte ve yüksek performans daha iyi bir özgeçmiş oluşturmaktadır. Öte yandan bireyin beklentisi arttıkça motivasyonu da artmaktadır.

Beklenti birçok faktörden etkilenmektedir. Örneğin yaş, cinsiyet, sosyo-ekonomik durum ve kültürel çeşitlilik gibi etkenler, geleceğe yön veren faktörlerdendir (Şimşek, 2012). Beklenti kuşaklara göre farklılık göstermektedir. Örneğin ergenler, bireysel beklentiler açısından, yetişkinlere oranla daha karamsar tutuma sahiptirler. $\mathrm{Bu}$ durum yetişkinlerin geçmiş deneyimlerinin bir sonucudur. Zira yetişkinler geçmişte elde ettikleri kazanımlar sayesinde geleceğe daha güvenle bakabilmektedirler. Ergenler ise gerek deneyim eksikliği gerekse içinde bulundukları biyo-fizyolojik dönemin etkileri nedeniyle gelecek konusunda daha karamsar olabilmektedirler (Tuncer, 2011). Bireylerin sosyo-ekonomik düzeyleri beklenti konusunda etkili olmaktadır. Çünkü sosyo-ekonomik düzeyin yüksek olması, başarı güdüsünü arttırmakta ve değişimi kolaylaştırmaktadır. Sosyo-ekonomik düzeyin düşük olması, gelecek beklentisi konusunda kaderci ve karamsar düşünceye yol açmaktadır (Tuncer, 2011).

Son yıllarda yapılan araştırmaların bir kısmı ergenlerin beklentilerine ilişkin tutarlılığ incelemiştir (Karademir, 2015; Koç ve Gün, 2007; Markus ve Nurius, 1986; Nurmi, 1991). Yapılan araştırmaların sonuçları, gençlerin beklentileri konusunda tutarlılığa işaret etmektedir. Buna göre, gençlerin gelecek beklentisi konusundaki düşünceleri meslek, eğitim ve aile kurmaya ilişkindir. Yaş farklılıkları dikkate alındığında, ileri yaşlardaki ergenlerin kariyer beklentisine odaklandıkları, cinsiyet farklılığı göz önüne alındığında ise aile kurma beklentisinin kızlarda, meslek ve eğitim beklentisinin ise erkeklerde odak noktası olduğu görülmektedir. Öz güven sabit değildir, insan yaşamı boyunca dinamik bir seyir izler. Öz güven ergenlik döneminde şekillenmeye başlar. Ancak sosyal çevre öz güven konusunda oldukça belirleyicidir. Başlangıçta ailenin yaklaşımı önemli iken bir süre sonra arkadaş etkisi ve okul yaşantısı devreye girmektedir (Günalp, 2007; Özbey, 2004). Öz güvenin, ergenliğe daha erken giren erkeklerde yüksek, kızlarda ise düşük olduğu ileri sürülmektedir (Santrock, 2013).

Gelecek beklentisi bir ölçüde bireyin sahip olduğu öz güvene işaret etmektedir. Öz güven, insan kişiliğinin en temel özelliklerinden biridir. Bandura’ya (1997) göre öz güven, bireyin kendisini değerli hissetme yargısıdır. Bir başka ifade ile bireyin kendi yetenek, güç ve kararlarına güvenmesidir. Öz güven kişiye belirli bir işi başarabileceğine yönelik inanç ve güven sağlar ve böylece kişi kendi dünyası üzerinde denetim ve egemenlik kurabilir (Göknar, 
2010). Hayatta karşılaşılan sorunlarla baş edebilme yeteneği olan öz güven tıpkı gelecek beklentisi gibi sonradan kazanılan bir duygudur. Başka bir tanımlamaya göre öz güven bireysel durumlara özgü veya geçici bir tutum olmayıp, aksine genel bir kişilik özelliğidir (Karademir, 2015).

Öz güven, iç ve dış öz güven olarak ikiye ayrılmaktadır. Kendini sevme, kendini tanıma, kendine açık hedefler koyma ve pozitif düşünce iç öz güvene işaret ederken, iletişim, kendini ifade edebilme, duygularını kontrol edebilme, dışarıya karşı kendisinden emin olma görüntüsü $d \iota s ̧$ öz güven olarak nitelendirilmektedir. Sağlıklı bir gelişim için iç ve dış öz güven dengesinin iyi kurulması gerekmektedir. Öz güvenin temelinde güçlü pozitif beklenti yer almaktadır. Çünkü bir konudaki negatif düşüncelerin fazlalığı o konudaki iş yapma kapasitesini azaltmaktadır. Başka bir ifade ile başarı ve öz güven doğru orantılı olarak birbirini etkilemektedir (Lindenfield, 2004).

Öz güven, öğrencilerin akademik performansını etkileyen önemli değişkenlerden biri olarak kabul edilmektedir (Lane, Hall ve Lane 2004). Zira, öz güven, motivasyon ve başarı arasında pozitif bir ilişki vardır. Birçok beceri gibi öz güvenin de düşük düzeyde olması başarıyı azaltmakta, öz güvenin yüksek olması başarıyı artırmaktadır. Öte yandan öz güven duygusu yüksek olan bireyler, karşılaştıkları problemleri çözmede daha başarılı olmaktadırlar (Owens, 2001).

\section{Araştırmanın Amacı}

$\mathrm{Bu}$ araştırmanın temel amacı; farklı lise türlerinde öğrenim gören öğrencilerin öz güven düzeyleri ve gelecek beklentileri arasındaki ilişkinin bazı değişkenler açısından incelenmesidir. Bu amaç doğrultusunda aşağıdaki sorulara yanıt aranmıştır:

1) Lise öğrencilerinin öz güven ve gelecek beklentilerinde cinsiyete göre anlamlı bir farklılaşma var mıdır?

2) Lise öğrencilerin devam ettikleri lise türüne göre öz güven ve gelecek beklentilerinde anlamlı bir fark var midır?

3) Lise öğrencilerin anne eğitim durumuna göre öz güven ve gelecek beklentilerinde anlamlı bir fark var midir?

4) Lise öğrencilerinin akademik başarıları ile öz güven ve gelecek beklentileri arasında anlamlı bir farklılık var midır?

5) Lise öğrencilerinin ailelerinin sosyo-ekonomik düzeyi ile öz güven ve gelecek beklentileri arasında anlamlı bir farklılık var mıdır? 
6) Lise öğrencilerinin öz güven ve gelecek beklentisi puanları arasındaki ilişki nasıldır?

\section{Yöntem}

Bu bölümde araştırmanın deseni, evren ve örneklem, veri toplama araçları ile verilerin toplanması ve analizine ilişkin detaylı bilgiye yer verilmiştir.

\section{Araştırma Deseni}

$\mathrm{Bu}$ araştırmada ilişkisel tarama modeli kullanılmıştır. İlişkisel desen, iki ya da daha çok sayıda değişken arasındaki değişimi belirlenmeye yönelik araştırmalarda kullanılmaktadır (Karasar, 2010). Bu çalışmada lise öğrencilerinin gelecek beklentileri ile öz güvenleri arasındaki ilişkinin belirlenmesi amaçlandığından iki değişken ortaya çıkmıştır. Bu değişkenler arasındaki ilişkinin belirlenmesi amacıyla ilişkisel tarama deseni kullanılmıştır. Betimsel nitelikteki çalışmanın verileri nicel yöntemlerle toplanmıştır.

\section{Evren ve Örneklem}

Bu araştırmanın evreni 2017-2018 yılında Kırşehir ilinde öğrenim gören 14239 lise öğrencisinden oluşmaktadır (Kırşehir İl Milli Eğitim Müdürlüğü, 2018). Araştırma örnekleminin belirlenmesinde uygun örnekleme tekniği kullanılmıştır. Uygun örnekleme çeşitli sınırlılıklar nedeniyle örneklemin kolay ulaşılabilir ve uygulama yapılabilir olmasını ifade etmektedir (Fraenkel, Wallen ve Hyun, 2012). Bu doğrultuda, 2017-2018 y1lında Kırşehir ilinde farklı lise türlerinde öğrenim gören 303 lise öğrencisi araştırmanın örneklemini oluşturmuştur. Araştırmanın örneklemini oluşturan öğrencilerin dağılımı Tablo 1'de verilmiştir.

Tablo 1. Örnekleme alınan öğrencilerin dağılımları

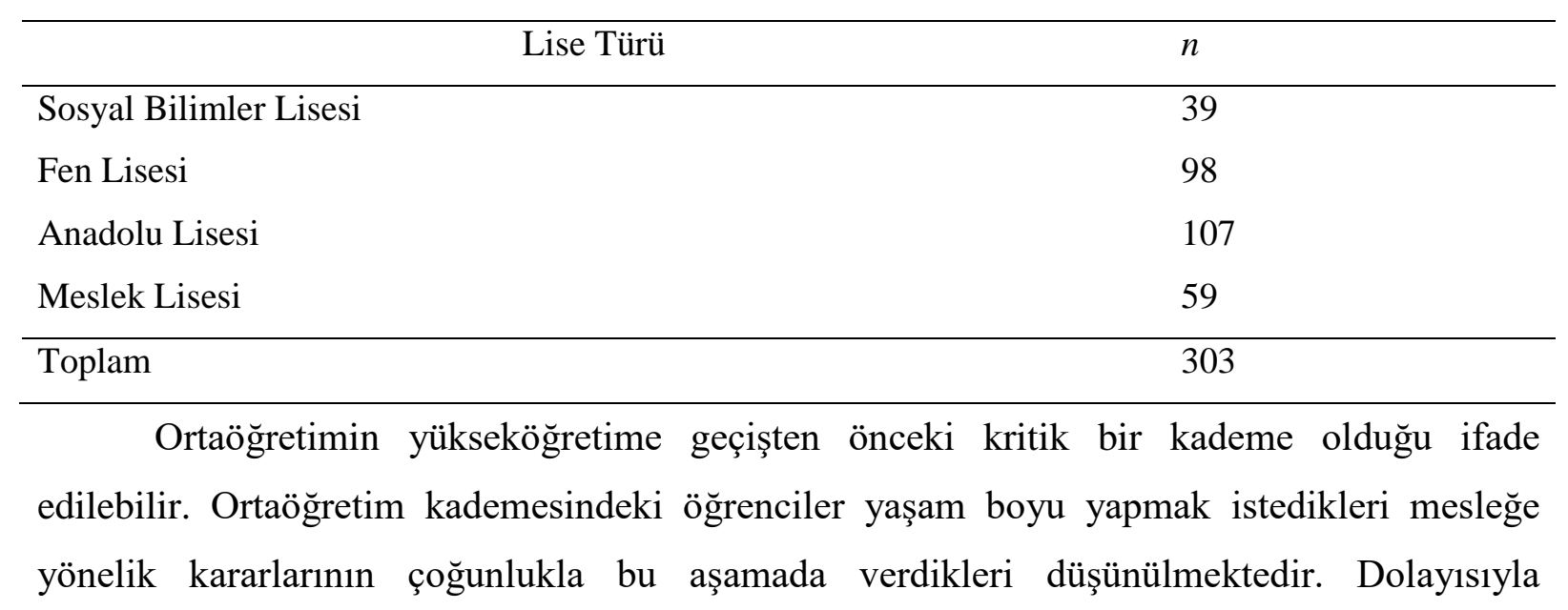


bireylerin geleceğe yönelik birtakım beklentilerinin lise öğrencisiyken olgunlaşmaya başladığı belirtilebilir. Bu sebepten çalışmanın örneklemini lise öğrencileri oluşturmaktadır.

\section{Veri Toplama Araçları}

Araştırma kapsamının verileri, Şimşek (2012) tarafından geliştirilen güvenirlik katsayısı .871 olan Gelecek Beklentisi Ölçeği ve Akın (2007) tarafından geliştirilen ve güvenirlik katsayısı .646 olan Öz-Güven Ölçeği kullanılarak elde edilmiştir. Gelecek beklentisi ölçeği, dört bölümden oluşan, geçerlik ve güvenirlik çalışması yapılmış, 33 maddelik bir ölçektir. Öz güven ölçeği ise 33 maddeden oluşmaktadır. Söz konusu çalışmada her iki ölçeğin güvenirlik katsayıları tekrar hesaplanmıştır. Buna göre Gelecek Beklentisi Ölçeğinin güvenirlik katsayısı .87, Öz-Güven Ölçeğinin güvenirliği .83 bulunmuştur. Verilerin normal dağılıp dağılmadığını belirlenmek için her iki ölçek için Shapiro Wilk testi sınanmış ve verilerin normal dağılım gösterdiği tespit edilmiştir [Öz güven (İstatistik=.93; $p=$ .052), Gelecek Beklentisi (İstatistik = .99; $p=.14$ )]. Veriler analiz edilirken normallik testi sonuçlarına bağlı olarak betimsel analizlerde parametrik testlerden yüzde (\%), frekans (F) iki değişken arası farkı belirlemek için T-Test ve ikiden fazla değişken arasındaki farklılığ belirlemek Tek Yönlü Varyans Analizi (ANOVA) üzere kullanılmıştır.

\section{Bulgular}

Bu bölümde araştırmanın alt problemlerine ilişkin bulgulara sırasıyla yer verilmiştir.

\section{Lise Öğrencilerinin Öz güven ve Gelecek Beklentisi Düzeylerinin Cinsiyet Değişkenine Göre Karşılaştırılması}

Lise öğrencilerinin cinsiyetlerine göre gelecek beklentisi düzeylerini belirlemek amacıyla yapılan t-testi sonuçları Tablo 2'de verilmiştir.

Tablo 2. Cinsiyet değişkenine göre lise öğrencilerinin öz güven ve gelecek beklentisi

$$
\text { düzeyleri }
$$

\begin{tabular}{llcccccc}
\hline & Grup & $n$ & $\overline{\mathrm{x}}$ & $S$ & $t$ & $d f$ & $p$ \\
\hline Öz güven & Erkek & 178 & 2.23 & .22 & -.20 & 301 & .84 \\
& Kadın & 125 & 2.24 & .18 & & & \\
\hline Gelecek & Erkek & 178 & 3.70 & .79 & 2.32 & 301 & .02 \\
Beklentisi & Kadın & 125 & 3.47 & .91 & & & \\
\hline$p<.05$ & & & & & & &
\end{tabular}


Tablo 2'ye göre kadın öğrencilerin öz güven düzeyleri $(\bar{x}=2.24)$ ile erkek öğrencilerin gelecek beklentileri $(\overline{\mathrm{x}}=2.23)$ arasında anlamlı bir fark bulunmamaktadır $\left(t_{(301)}=-.20 ; p>.05\right)$. Diğer taraftan kadın öğrencilerin gelecek beklentileri $(\bar{x}=3.47)$ ile erkek öğrencilerin gelecek beklentileri $(\bar{x}=3.70)$ arasında erkek öğrenciler lehine anlamlı fark bulunmaktadır $\left(t_{(301)}=\right.$ $2.32 ; p<.05)$.

\section{Lise Öğrencilerin Öz güven ve Gelecek Beklentilerinin Lise Türüne Göre Karşılaştırılması}

Öğrencilerin devam ettikleri lise türüne göre öz güven ve gelecek beklentisi puanlarının dağılımı, puanlar arası farkı gösteren Tek Yönlü Varyans Analiz Testi ve farkın kaynağını gösteren LSD analiz sonuçları Tablo 3 ve Tablo 4'te verilmiştir.

Tablo 3. Öğrencilerin öz güven ve gelecek beklentisi puanlarının lise türüne göre dağılımı

\begin{tabular}{llllll}
\hline & & Öz güven & \multicolumn{3}{c}{ Gelecek Beklentisi } \\
\hline \multicolumn{1}{c}{ Lise Türü } & $n$ & $\overline{\mathrm{x}}$ & $S$ & $\overline{\mathrm{x}}$ & $S$ \\
\hline Sosyal Bilimler Lisesi & 39 & 2.26 & .16 & 3.61 & .77 \\
Fen Lisesi & 98 & 2.22 & .23 & 3.28 & .83 \\
Anadolu Lisesi & 107 & 2.28 & .17 & 3.77 & .82 \\
Meslek Lisesi & 59 & 2.19 & .23 & 3.83 & .83 \\
\hline Toplam & 303 & 2.24 & .20 & 3.61 & .85 \\
\hline
\end{tabular}

Tablo 3 incelendiğinde, öğrencilerinin öz güven ve gelecek beklentisi puanlarının lise türüne göre farklılık gösterdiği anlaşılmaktadır. Buna göre öz güven puanı en yüksek olan lise türü Anadolu Lisesi $(\bar{x}=2.28)$ iken, Meslek Lisesi öğrencilerinin puanları $(\bar{x}=2.19)$ en düşüktür. Diğer taraftan Meslek Lisesi öğrencilerinin gelecek beklentisi puanları $(\overline{\mathrm{x}}=3.83)$ grupta yer alan diğer öğrencilerin puanlarından daha yüksek iken Fen Lisesi öğrencilerinin ortalama puanları $(\bar{x}=3.28)$ en düşük düzeydedir. Öğrencilerin öz güven ve gelecek beklentisi puanlarının lise türüne göre farklılığının anlamlılığını test etmek amacı ile yapılan Tek Yönlü Varyans Analizi (ANOVA) sonuçları Tablo 4’te verilmiştir.

Tablo 4. Öğrencilerin Öz güven ve Gelecek Beklentisi puanlarının lise türüne göre farkı

\begin{tabular}{lllllll}
\hline & Varyansın Kaynağ 1 & $S$ & $d f$ & $m s$ & $F$ & $p$ \\
\hline Öz güven & Gruplar arası & .42 & 3 & .14 & 3.31 & .02 \\
& Gruplar içi & 12.59 & 299 & .04 & & \\
& Toplam & 13.01 & 302 & & & \\
\hline
\end{tabular}




\begin{tabular}{lllllll}
\hline Gelecek & Gruplar aras1 & 16.14 & 3 & 5.38 & 7.96 & .00 \\
Beklentisi & Gruplar içi & 202.00 & 299 & .67 & & \\
& Toplam & 218.14 & 302 & & & \\
& & & & & & \\
\hline
\end{tabular}

$p<.05$

Tablo 4'e göre; öğrencilerin devam ettikleri lise türüne göre öz güven $\left(F_{(299)}=3.31\right.$; $p<.05)$ ve gelecek beklentisi $\left(F_{(299)}=7.96 ; p<.05\right)$ puanları istatistiksel olarak anlamlı farklılık oluşturmaktadır. Söz konusu farkın kaynağını anlamak için yapılan LSD test sonucuna göre Anadolu, Fen ve Meslek Lisesi öğrencilerinin öz güven puanları karşılaştırıldığında, Anadolu Lisesi öğrencileri lehine anlamlı farklılık bulunmaktadır. Diğer taraftan Fen Lisesi öğrencilerinin gelecek beklentisi puanları ile diğer lise öğrencilerinin puanları karşılaştırıldığında Fen Lisesi öğrencileri aleyhine fark bulunmuştur.

\section{Lise Öğrencilerin Öz güven ve Gelecek Beklentilerinin Anne Eğitim Durumuna Göre Karşılaştırılması}

Öğrencilerin anne eğitim durumuna göre öz güven ve gelecek beklentisi puanlarının dağılımı, puanlar arası farkı gösteren Tek Yönlü Varyans Analiz Testi ve farkın kaynağını gösteren LSD analiz sonuçları aşağıda tablolar halinde verilmiştir.

Tablo 5. Öğrencilerin öz güven ve gelecek beklentisi puanlarının anne eğitim durumuna göre dağılımı

\begin{tabular}{llllll}
\hline & Öz güven & \multicolumn{3}{c}{ Gelecek Beklentisi } \\
\hline Anne eğitim & $n$ & $\overline{\mathrm{x}}$ & $S D$ & $\overline{\mathrm{x}}$ & $S D$ \\
\hline İlkokul & 97 & 2.25 & .19 & 3.71 & .89 \\
Ortaokul & 77 & 2.21 & .22 & 3.78 & .74 \\
Lise & 85 & 2.26 & .19 & 3.52 & .79 \\
Üniversite & 44 & 2.23 & .22 & 3.21 & .90 \\
\hline Toplam & 303 & 2.24 & .20 & 3.60 & .84 \\
\hline
\end{tabular}

Tablo 5 incelendiğinde, annesi lise mezunu olan öğrencilerinin öz güven puanları $(\bar{x}=2.26)$ en yüksek iken annesi ortaokul mezunu olan öğrencilerinin puanları $(\bar{x}=2.21)$ en düşüktür. Buna karşılık annesi ortaokul mezunu olan öğrencilerinin gelecek beklentisi puanları $(\bar{x}=3.78)$ grupta yer alan diğer öğrencilerin puanlarından daha yüksek iken annesi üniversite mezunu olan öğrencilerinin ortalama puanları $(\bar{x}=3.21)$ en düşük düzeydedir. Öğrencilerin öz güven ve gelecek beklentisi puanlarında anne eğitim durumuna göre oluşan 
farklılığının anlamlılığını test etmek amacı ile yapılan Tek Yönlü Varyans Analizi sonuçları Tablo 6'da verilmiştir.

Tablo 6. Öğrencilerin öz güven ve gelecek beklentisi puanlarının anne eğitim durumuna göre fark1

\begin{tabular}{lllllll}
\hline & Varyansın Kaynağı & $S$ & $d f$ & $M S$ & $F$ & $p$ \\
\hline Öz güven & Gruplar arası & .10 & 3 & .03 & .79 & .49 \\
& Gruplar içi & 12.90 & 299 & .04 & & \\
& Toplam & 13.00 & 302 & & & \\
\hline Gelecek Beklentisi & Gruplar arasi & 10.74 & 3 & 3.58 & 5.16 & .00 \\
& Gruplar içi & 207.39 & 299 & .69 & & \\
& Toplam & 218.14 & 302 & & & \\
\hline
\end{tabular}

$p<.05$

Tablo 6’ya göre; öğrencilerin anne eğitim durumuna göre öz güven puanları anlamlı farklılık oluşturmazken $\left(F_{(299)}=.79 ; p>.05\right)$, gelecek beklentisi puanları arasında istatistiksel olarak anlamlı farklılık bulunmaktadır $\left(F_{(299)}=5.16 ; \quad p<.05\right)$. Söz konusu farkın kaynağını belirlemek amaciyla yapılan LSD testi sonucuna göre annesi üniversite mezunu olanlar ile diğer grupta yer alan öğrenciler arasında annesi üniversite mezunu olanlar aleyhine farklılık olduğu görülmüştür.

\section{Lise Öğrencilerinin Öz güven ve Gelecek Beklentilerinin Okul Memnuniyetine Göre Karşılaştırılması}

Öğrencilerin okul memnuniyet düzeylerine göre öz güven ve gelecek beklentisi puanlarının dağılımı, puanlar arası farkı gösteren Tek Yönlü Varyans Analiz Testi ve farkın kaynağını gösteren LSD analiz sonuçları aşağıda tablolar şeklinde verilmiştir.

\section{Lise Öğrencilerinin Öz güven ve Gelecek Beklentilerinin Akademik Başarılarına Göre Karşılaştırılması}

Öğrencilerin akademik başarılarına göre öz güven ve gelecek beklentisi puanlarının dağılımı, puanlar arası farkı gösteren Tek Yönlü Varyans Analiz Testi ve farkın kaynağını gösteren LSD analiz sonuçları aşağıda tablolar şeklinde verilmiştir.

Tablo 7. Öğrencilerin öz güven ve gelecek beklentisi puanlarının akademik başarı düzeylerine göre dağılımı

Öz güven Gelecek Beklentisi




\begin{tabular}{llllll}
\hline Akademik başar1 & $n$ & $\overline{\mathrm{x}}$ & $S D$ & $\overline{\mathrm{x}}$ & $S D$ \\
\hline $0-45$ & 15 & 2.26 & .31 & 3.76 & .83 \\
$46-69$ & 98 & 2.25 & .20 & 3.73 & .82 \\
$70-89$ & 117 & 2.23 & .18 & 3.62 & .87 \\
$90-100$ & 73 & 2.23 & .21 & 3.37 & .81 \\
\hline Toplam & 303 & 2.24 & .20 & 3.60 & .84 \\
\hline
\end{tabular}

Tablo 7 incelendiğinde, akademik başarıları düzeyleri 0-45 olan öğrencilerin öz güven puanları $(\bar{x}=2.26)$ en yüksek iken başarı düzeyleri 70-100 olan öğrencilerin puanları $(\bar{x}=2.23)$ en düşüktür. Diğer taraftan akademik başarı ortalamaları 0-45 olan öğrencilerin gelecek beklentisi puanları $(\bar{x}=3.76)$ grupta yer alan diğer öğrencilerin puanlarından daha yüksek iken başarı ortalamaları 90-100 olan öğrencilerin ortalama puanları $(\bar{x}=3.37)$ en düşük düzeydedir. Öğrencilerin öz güven ve gelecek beklentisi puanlarında oluşan akademik başarı düzeylerine göre farklılığının anlamlılığını test etmek amacı ile yapılan Tek Yönlü Varyans Analizi sonuçları Tablo 8'de verilmiştir.

Tablo 8. Öğrencilerin öz güven ve gelecek beklentisi puanlarının akademik başarı düzeylerine göre fark1

\begin{tabular}{lllllll}
\hline & Varyansın Kaynağı & $S$ & $d f$ & $M S$ & $F$ & $p$ \\
\hline Öz güven & Gruplar arası & .02 & 3 & .00 & .17 & .91 \\
& Gruplar içi & 12.98 & 299 & .04 & & \\
& Toplam & 13.00 & 302 & & & \\
\hline \multirow{2}{*}{ Gelecek Beklentisi } & Gruplar arası & 5.99 & 3 & 2.00 & 2.81 & .03 \\
& Gruplar içi & 212.14 & 299 & .71 & & \\
& Toplam & 218.14 & 302 & & & \\
\hline
\end{tabular}

$p<.05$

Tablo 8'e göre; öğrencilerin akademik ortalamalarına göre öz güven puanları arasında anlamlı fark yoktur $\left(F_{(299)}=.17 ; p>.05\right)$. Buna karşılık olarak öğrencilerin gelecek beklentisi puanları istatistiksel olarak anlamlı farklılık oluşturmaktadır $\left(F_{(299)}=2.81 ; p<.05\right)$. Söz konusu farkın kaynağını anlamak için yapılan LSD test sonucuna göre akademik başarı düzeyi 90-100 (pekiyi) olan öğrenciler ile başarı düzeyleri 46-69 (orta) ve 70-89 (iyi) olan öğrencilerinin öz güven puanları karşılaştırıldığında, akademik başarı düzeyleri 90-100 olan öğrenciler aleyhine anlamlı farklılık vardır. 


\section{Lise Öğrencilerinin Öz güven ve Gelecek Beklentilerinin Ailenin Sosyo-Ekonomik Durumuna Göre Karşılaştırılması}

Öğrencilerin ailelerinin sosyo-ekonomik durumuna göre öz güven ve gelecek beklentisi puanlarının dağılımı, puanlar arası farkı gösteren Tek Yönlü Varyans Analiz Testi ve farkın kaynağını gösteren LSD analiz sonuçları aşağıda tablolar şeklinde verilmiştir.

Tablo 9. Öğrencilerin öz güven ve gelecek beklentisi puanlarının ailenin sosyo-ekonomik durumuna göre dağılımı

\begin{tabular}{lllllc}
\hline & \multicolumn{2}{l}{ Öz güven } & \multicolumn{3}{l}{ Gelecek Beklentisi } \\
\hline Sosyo ekonomik Durum & $n$ & $\overline{\mathrm{x}}$ & $S D$ & $\overline{\mathrm{x}}$ & $S D$ \\
\hline 1300 ve alt1 & 51 & 2.18 & .21 & 3.57 & .80 \\
$1300-3000$ & 149 & 2.25 & .19 & 3.73 & .84 \\
\multirow{2}{*}{3000 ve üzeri } & 103 & 2.25 & .21 & 3.44 & .84 \\
\hline Toplam & 303 & 2.24 & .20 & 3.60 & .84
\end{tabular}

Tablo 9 incelendiğinde, ailenin sosyo-ekonomik durumuna göre aile geliri 1300 TL ve üzeri olan öğrencilerin öz güven puanları $(\bar{x}=2.25)$ en yüksek iken aile geliri 1300TL'nin altında olan öğrencilerin puanları $(\overline{\mathrm{x}}=2.18)$ en düşüktür. Diğer taraftan aile geliri 13003000TL olan öğrencilerin gelecek beklentisi puanları $(\overline{\mathrm{x}}=3.73)$ grupta yer alan diğer öğrencilerin puanlarından daha yüksek iken aile geliri 3000TL ve üzeri olan öğrencilerin ortalama puanları $(\bar{x}=3.44)$ en düşük düzeydedir. Öğrencilerin aile gelir durumuna göre öz güven ve gelecek beklentisi puanlarında oluşan farklılığının anlamlılığını test etmek amacı ile yapılan Tek Yönlü Varyans Analizi sonuçları Tablo 10’da verilmiştir.

Tablo 10. Öğrencilerin Öz güven ve Gelecek Beklentisi puanlarının ailenin sosyo ekonomik durumuna göre fark1

\begin{tabular}{lllllll}
\hline & Varyansın Kaynağı & $S$ & $d f$ & $M S$ & $F$ & $p$ \\
\hline Öz güven & Gruplar arası & .23 & 2 & .11 & 2.80 & .06 \\
& Gruplar içi & 12.77 & 300 & .04 & & \\
& Toplam & 13.00 & 302 & & & \\
\hline Gelecek Beklentisi & Gruplar arası & 5.05 & 2 & 2.52 & 3.55 & .03 \\
& Gruplar içi & 213.08 & 300 & .71 & & \\
& Toplam & 218.14 & 302 & & & \\
\hline
\end{tabular}

$p<.05$

Tablo 10’a göre; öğrencilerin ailenin sosyo-ekonomik durumuna göre öz güven puanları arasında anlamlı farklılık yoktur $\left(F_{(300)}=2.80 ; \quad p>.05\right)$. Buna karşılık olarak 
öğrencilerin gelecek beklentisi puanları istatistiksel olarak anlamlı farklılık oluşturmaktadır $\left(F_{(300)}=3.55 ; p<.05\right)$. Söz konusu farkın kaynağını anlamak için yapılan LSD test sonucuna göre aile geliri 1300-3000 TL olan öğrenciler gelecek beklentisi puanları ile aile geliri 3000TL ve üzeri olan öğrencilerin arasında aile geliri 1300-3000TL olan öğrencilerin lehine anlamlı farklılık olduğu bulgusuna ulaşılmıştır.

\section{Lise Öğrencilerinin Öz Güven Düzeyleri ve Gelecek Beklentileri Arasındaki İlişki}

Tablo 11'de öğrencilerin öz güven düzeyleri ile gelecek beklentisi arasındaki korelasyon analizine yer verilmiştir.

Tablo 11. Öz güven ve gelecek beklentisi arasındaki ilişki düzeyi

\begin{tabular}{llll}
\hline & $r$ & $p$ & Toplam \\
\hline Öz Güven ve Gelecek Beklentisi & .03 & 0.57 & 303 \\
\hline
\end{tabular}

Tablo 11 incelendiğinde öğrencilerin öz güven düzeyleri ile gelecek beklentisi arasında anlamlı bir ilişki olmadığı görülmektedir ( $\mathrm{p}>.05)$.

\section{Tartışma, Sonuç ve Öneriler}

$\mathrm{Bu}$ bölümde, araştırma verilerinin analizi sonucunda elde edilen bulgulara dayalı olarak edilen sonuçlara yer verilmiştir.

\section{Lise Öğrencilerinin Gelecek Beklentilerine İlişkin Sonuçlar}

Araştırmadan elde edilen sonuçlara göre, lise öğrencilerinin gelecek beklentileri cinsiyete göre anlamlı bir şekilde farklılaşmaktadır. Buna göre kız öğrencilerin gelecek beklentileri, erkek öğrencilere kıyasla manidar biçimde düşük bulunmuştur. $\mathrm{Bu}$ durum, kadınların psikolojik özelliklerinden kaynaklanıyor olabilir. Diğer bir ifade ile kadınların duygu durumlarının ve sorumluluk duyarlılıklarının gelecek hakkında daha fazla kaygı duymalarına yol açmış olabilir. Tuncer (2011), meslek yüksekokulu öğrencilerinin gelecek beklentileri arasında cinsiyet değişkenine göre kız öğrenciler lehine anlamlı fark bulurken, Güleri (1998) kızlar ve erkekler arasında gelecek hakkındaki iyimserlik düşünceleri bakımından anlamlı bir farklılık olmadığını saptamıştır. Şimşek (2012) tarafından yapılan bir araştırmada ise lise öğrencilerinin gelecek beklentilerinin cinsiyete göre farklılaşmadığı rapor edilmiştir.

Öğrencilerin devam ettikleri lise türü değişkenine göre gelecek beklentisi puanları arasında istatistiksel olarak anlamlı farklılık yoktur. Meslek Lisesi öğrencilerinin gelecek 
beklentileri, diğer lise türlerindeki öğrencilerden yüksek bulunurken, Fen Lisesi öğrencilerinin beklenti düzeylerinin en düşük olduğu görülmüştür. Fen Lisesi öğrencilerinin gelecek beklentilerinin düşük olması, bulundukları lise türü nedeniyle, akademik başarıya bağlı beklenti oluşturmalarından ve alternatif meslek seçimlerinin sınırlanmış olmasından kaynaklandığı ileri sürülebilir. Nitekim Uluçay, Özpolat, İşgör ve Taşkesen (2014) tarafindan yapılan bir başka araştırmada, türüne göre lise öğrencilerinin gelecek beklentilerinin farklılık gösterdiği, en yüksek gelecek beklentisine sahip öğrencilerin Spor Lisesi öğrencileri olduğu rapor edilmiştir. Koçak ve Çepni (2017) tarafından yapılan bir çalışmada ise kariyerlerine odaklanan öğrencilerin beklentilerinin arttı̆̆ tespit edilmiştir.

Lise öğrencilerinin anne eğitim durumuna göre gelecek beklentisi puanlarının istatistiksel olarak anlamlı olduğu sonucuna ulaşılmıştır. Buna göre gelecek beklentisi bakımından, annesi üniversite mezunu olan öğrenciler ile diğer grupta yer alan öğrenciler arasında annesi üniversite mezunu olanlar aleyhine farklılık bulunmaktadır. Diğer taraftan üniversite mezunu olmayan annelerin, gelecek beklentisi bakımından çocukları üzerinde daha etkili oldukları, üniversite mezunu annelerin ise ekonomik düzeylerinin yüksek olması ihtimaline bağlı olarak, çocukları üzerinde gelecek beklentisi oluşturma konusunda yetersiz oldukları söylenebilir. Tuncer'in (2011) araştırmasında ise meslek yüksekokulu öğrencilerinin gelecek beklentilerinin anne ve baba eğitim durumuna göre anlamlı biçimde farklılaşmadığı saptanmıştır.

Bulgulardan elde edilen bir diğer sonuca göre, öğrencilerin akademik başarıları ile gelecek beklentisi puanları arasında istatistiksel olarak anlamlı farklılık bulunmaktadır. Akademik başarı düzeyi pekiyi (90-100) olan öğrenciler ile başarı düzeyleri iyi (70-89) ve orta (46-69) olan öğrencilerinin gelecek beklentisi puanları kıyaslandığında, akademik başarı düzeyi pekiyi olan öğrenciler aleyhine anlamlı fark olduğu görülmüştür. $\mathrm{Bu}$ durum girecekleri merkezi sınavların öğrenciler üzerinde oluşturduğu kaygının bir sonucu şeklinde yorumlanabilir. Bazı araştırmalarda akademik başarı düzeyinin gençlerin umut ve umutsuzluk düzeylerine anlamlı etkileri olduğu rapor edilmiştir. Örneğin, Çelikel-Çam ve Erkorkmaz (2008) tarafından yapılan bir araştırmada başarı düzeyi düşük olan üniversite öğrencilerinin umutsuzluk ve depresif belirti düzeylerinin manidar şekilde yüksek olduğu görülmüştür.

Ailenin sosyo-ekonomik durumu öğrencilerin gelecek beklentisi puanlarında anlamlı farklılığa yol açmaktadır. Aile geliri orta düzeyde (1300-3000 TL) olan öğrencilerin gelecek beklentisi puanları ile aile geliri yüksek düzeyde (3000 TL ve üzeri) olan öğrenciler arasında geliri orta düzeyde olanlar lehine anlamlı farklılıklar olduğu görülmüştür. Bu durum tipik orta 
sınıf davranışının bir yansıması olarak değerlendirilebilir. Bir başka ifade ile orta sınıf ailelerin sınıf atlama konusundaki olumlu beklentisi ile bulunduğu sınıfı kaybetme kaygısının bir bileşkesi olarak gelecek beklentisi oluşturma konusunda diğer sınıflara kıyasla daha avantajlı oldukları söylenebilir. Bir başka araştırmada baba eğitim durumu lisansüstü olan çocukların daha yüksek gelecek beklentisine sahip oldukları belirlenmiş ve bu sonucun, eğitim düzeyi yüksek ailelerin çocuklarıyla daha sağlıklı bir iletişim kurmalarından ve ebeveynlerin başarı öyküsünün gençlerin gelecek beklentilerine olumlu yansıdığı şeklinde yorumlanmıştır (Tuncer, 2011).

\section{Lise Öğrencilerinin Öz güven Düzeylerine İlişkin Sonuçlar}

Araştırmanın sonuçlarına göre cinsiyet değişkeni öz güven açısından anlamlı bir fark oluşturmamaktadır. Başka bir araştırmada mental (psikolojik) iyi olma puan ortalamaları ile cinsiyet değişkeni arasındaki fark anlamlı bulunmamıştır (Gönener, Öztürk ve Yılmaz, 2017). Karademir (2015) tarafından gerçekleştirilen bir başka araştırmada cinsiyet değişkenine göre öz güven puan ortalamaları arasında anlamlı bir fark olmadığı belirlenirken, Öztürk'ün (2017) araştırmasında cinsiyet değişkeninin öz güveni yordamadığı bulgusuna ulaşılmıştır. Bazı araştırma bulguları cinsiyet değişkeninin öz güvenle ilişkili olduğunu gösterirken, bazı araştırmalarda erkeklerin bazılarında ise kızların daha yüksek öz güvene sahip olduklarına dair sonuçlar elde edilmiştir. Örneğin Kanadıkırık, Kılıç ve Kılıç (2013) erkeklerin öz güvenlerinin kızlardan daha yüksek olduğu bulgusuna ulaşırken, Şar, Avcu ve Işıklar (2010) lisans öğrenimi gören kızların erkeklere kıyasla daha yüksek öz güvene sahip olduklarını rapor etmişlerdir. Lipingh (2000), Sarıçam (2012), Kanadıkırık, Kılıç ve Kılıç (2013), tarafından yapılan çalışmalarda erkeklerin öz güvenleri daha yüksek bulunurken, Karadeniz ve Özdemir (2006) tarafından yapılan bir araştırmada erkek öğrencilerin öz yeterlik algılarının kız öğrencilere göre daha düşük olduğu görülmüştür. Kadınlar üzerinde yapılan bir araştırmada gençlik kampı kadın lider adaylarının öz güven düzeylerinin daha yüksek olduğu tespit edilmiştir (Esentaş, Işı1kgöz, Doğan ve Şahin, 2017). Bazı araştırmalar öz güven düzeyinin kızlarda daha yüksek olduğuna işaret ederken (Lackovic-Grgin ve Dekovic, 1990) bazı araştırmalarda ise erkeklerin kadınlara oranla daha yüksek psikolojik iyi olma düzeyine sahip oldukları belirlenmiştir (Haring, Stock ve Okun, 1984). Araştırma sonuçları dikkate alındığında, cinsiyetin öz güven üzerindeki etkisi konusunda kesin bir yargıya varmanın mümkün olmadığı söylenebilir. Cinsiyet değişkeni ile öz güven düzeyi arasında anlamlı farklılık olmamasının bir takım çevresel faktörlerle ilişkili olduğu düşünülebilir. Özellikle 
ülkemiz gibi geleneksel toplumlarda çocukların (kız-erkek) birçok ihtiyaçlarının aileleri tarafından karşılanmasının ve çocukların koruyucu ebeveyn tutumu ile yetiştirilmiş olmalarının bu sonucu etkilediği düşünülmektir. Nitekim bazı araştırmalarda, öz güvenin kalıtsal bir özellik olmadığı, aile, okul ve çevre gibi faktörlerin etkisi ile şekillendiği ileri sürülmektedir (Göknar, 2010).

Öğrencilerin anne eğitim düzeyi ergenlerin öz güven puanlarında istatistiksel olarak anlamlı farklılık oluşturmamaktadır. Öztürk'ün (2017) araştırmasında da anne eğitim düzeyinin öğrencilerin öz güven düzeylerini yordamadığı bulgusuna ulaşılmıştır. Oysa Çelik ve Onay (2014) anne eğitim durumuna göre öz güven arasında pozitif yönlü anlamlı bir ilişki olduğuna işaret etmiştir. Ayrıca Çelik (2014), anne eğitim seviyesinin ortaokul öğrencilerinin öz güvenlerini yordadığı bulgusuna ulaşmış ve anne eğitim seviyesi yüksek olan öğrencilerin öz güven düzeylerinin de yüksek olduğunu rapor etmiştir. Süpçeler (2016) ise ergenlerin öz güven düzeylerinin anne eğitim durumuna göre değiştiğini; annesi okuma yazma bilmeyen ergenlerin, annesi üniversite mezunu olan ergenlere göre daha yüksek öz güvene sahip oldukları bulgusuna ulaşmıştır. $\mathrm{Bu}$ araştırmada elde edilen sonuçlar ile diğer araştırma sonuçları arasındaki farklılık, anne eğitim düzeyinin öz güven üzerindeki etkisi konusunda kesin bir yargıya varmanın mümkün olmadığını göstermektedir.

Araştırmadan elde edilen bir diğer sonuca göre, öğrencilerin akademik ortalamaları ile öz güven puanları arasında istatistiksel olarak anlamlı bir farklılık yoktur. Anlamlı farklılık olmamakla birlikte, öğrencilerin akademik başarıları arttıkça öz güvenlerinin düştüğü gözlenmiştir. Bu sonuç, okulların öğrencileri başarılı yapsa bile öz güven konusunda yeterince etkili olamadığı şeklinde yorumlanabilir. Bu sonuç, akademik yönden başarılı olmanın öz güven ile doğrudan ilişskisi olmadığı şeklinde de yorumlanabilir. Bu sonuç, Öztürk (2017), Karademir (2015) ile Patır Erkek'in (2016) çalışmalarında elde ettikleri, akademik başarı değişkeninin öz güveni yordamadığına ilişkin sonuçlar ile benzerlik göstermektedir. Başka bir araştırmada da akademik not ortalamalarına göre öğrencilerin öz güven düzeyleri arasında istatistiksel olarak anlamlı fark bulunmamıştır (Karademir, 2015).

Esasen yüksek not ortalamasının öğrencilerin öğrenme isteklerini ve güdülenme düzeylerini artıracağı ve bu durumun öz güven düzeylerini yükselteceği beklenmektedir. Ancak bazı durumlarda sosyal aktivitelere yönelen ve akademik başarısını önemsemeyen öğrencilerin öz güven düzeyleri de yüksek olabilmektedir. Böylesi durumlarda ödünleme mekanizması yoluyla sosyal etkinliklerde elde edilen başarının öğrencilerin akademik başarıyı önemsemelerini engellemiş olabilir. Nitekim alan yazın incelendiğinde düzenli spor yapmanın 
veya fiziksel etkinliklere katılmanın bireylerin benlik saygısı ve öz güven gibi olumlu davranışlar geliştirmelerinde etkili olduğu vurgulanmaktadır (Bısgın ve Ustun, 2013; Demirel, 2013; Slutzky, Simpkins, 2009). Yine Zorba’ya (2012) göre düzenli olarak spor yapmak bireylerde öz saygının gelişimine, öz güvenin artmasına olumlu katkı yapmaktadır.

Alanyazında akademik başarı değişkeninin öz güven ile ilişkili olduğunu gösteren araştırmalar da bulunmaktadır. Örneğin Soner (2000) çalışmasında, öz güveninin akademik başarıyı olumlu yönde etkilediğini, Çelik (2014) ise kendini başarılı gören ortaokul öğrencilerinin öz güven puan ortalamalarının daha yüksek olduğunu bulmuştur. Kutlu (2001) da benzer şekilde öğrencilerin öz güven düzeylerinin akademik performanslarını etkilediği bulgusuna ulaşmıştır. Andrew (1998), Kloosterman (1988) ve Pajares (1996) de akademik başarı ile öz güven arasındaki güçlü ilişkiye vurgu yapmışlardır. Öz güvenin başarının önemli bir belirleyicisi olduğu düşünülmektedir. Bouffard-Bouchard, Parent ve Larivee (1991), düşük öz-yeterlilik düzeyine sahip öğrencilerin yüksek öz-yeterlilik düzeyine sahip öğrencilere kıyasla verilen görevleri tamamlama konusunda daha az 1srarcı olduklarını, Devenport (2003) ise düşük öz-yeterlilik düzeyine sahip öğrencilerin problemler karşısında kaçınma davranışı sergilediklerini, yüksek öz-yeterlilik düzeyine sahip öğrencilerin ise problemlerle başa etme stratejilerini kullanmaya odaklandıklarını belirtmişlerdir (akt. Lane vd., 2004).

\section{Lise Öğrencilerinin Öz güven Düzeyleri ile Gelecek Beklentisi Arasındaki İlişkiye Dair} Sonuçlar

$\mathrm{Bu}$ araştırmada lise öğrencilerinin öz güven düzeyleri ile gelecek beklentileri arasında anlamlı bir ilişki olmadığı ortaya konulmuştur. Bu çalışmanın aksine, alanyazındaki bulgular öz güven ve gelecek beklentileri arasında anlamlı ilişki olduğu yönündedir. Geleceğe yönelik olumlu beklentilere sahip ergenlerin öznel iyi oluş düzeyleri de anlamlı düzeyde yükselmektedir. Bazı araştırmalarda ergenlerde psikolojik iyi olma ile mutluluk arasında anlamlı ve pozitif korelasyon tespit edilirken (Gönener, Öztürk ve Yılmaz, 2017), bazılarında geleceğe yönelik olumlu beklentilere sahip ergenlerin öznel iyi oluş düzeylerinin de anlamlı ve önemli düzeyde yükseldiği rapor edilmiştir (Eryılmaz, 2011).

Alanyazın sonuçlarına göre bireylerin öznel iyi oluşlarını etkileyen üç önemli faktör bulunmaktadır. Bu faktörler kişilik özellikleri, amaca yönelik etkinlikler ve demografik özellikleridir. Bir çalışmaya göre kişilik özellikleri bireylerin öznel iyi oluşlarını \%50 oranında açıklarken, amaca yönelik etkinlikler \%40, demografik özellikler ise \%10 oranında açıklamaktadır (Lyubomirsky, Sheldon ve Schkade, 2005; akt. Eryılmaz, 2011). 
Öte yandan literatür bulguları, bireylerin umut düzeylerinin yükselmesinin öznel iyi oluş düzeylerini de yükselttiğini ortaya koymaktadır (Argyle, 2001; Snyder, 2000). Bu çalışmada olumlu gelecek beklentisine sahip olma ile ergenlerin öznel iyi oluşları arasında anlamlı ilişkiler bulunmuştur. Bu bulgunun nedeni, geleceğe yönelen insanların sergiledikleri özellikler olabilir. Literatür incelendiğinde, gelecek odaklı bireylerin, olumlu işlevsellikler sergiledikleri, sağlık kontrolü yaptırdıkları ve daha az psikopatoloji sergiledikleri bulunmuştur (Guarino, Pascalis, Di Chiacchio, 1999; Kazakina, 1999).

\section{Makalenin Bilimdeki Konumu}

\section{Eğitim Bilimleri Bölümü/Eğitim Programları ve Öğretim}

\section{Makalenin Bilimdeki Özgünlüğü}

Öğrencilerin akademik performansları üzerinde etkili bir değişken olan öz güven ile motivasyon ve başarı arasında olumlu bir ilişki vardır. Dolayısıyla öğrencinin öz güveninin yüksek olması akademik başarısını artırabilir. Öz güvenin temelinde güçlü pozitif beklenti yer almaktadır. Öğrencilerin gelecek beklentilerine ilişkin alanyazında çeşitli çalışmalar mevcuttur. Ancak öz güven ve gelecek beklentileri arasındaki ilişkiyi belirlemeye yönelik herhangi bir çalışma yoktur. Bu sebepten öğrencilerin öz güvenleri ile gelecek beklentileri arasındaki ilişkinin belirlenmesi önem arz etmektedir.

\section{Kaynaklar}

Akın, A. (2007). Öz-Güven Ölçeği'nin geliştirilmesi ve psikometrik özellikleri. Abant İzzet Baysal Üniversitesi Eğitim Fakültesi Dergisi, 7(2), 167-176.

Andrew, S. (1998). Self-efficacy as a predictor of academicperformance in science. Journal of Advanced Nursing, 27, 596-603.

Argyle, M. (2001). The psychology of happiness. East Sussex: Routledge Press.

Bandura, A. (1977). Self-efficacy: Toward a unifying theory of behavioral change. Psychological Review, 84(2), 191-215.

Bisgin H. \& Ustun, U. D. (2013). Analysis of elite male wrestlers' social comparison levels according to socio-demographic backgrounds. Turkish Journal of Sport and Exercise, 15(3), 60-63. 
Bouffard-Bouchard, T., Parent, S. \& Larivee, S. (1991). Influence of self-efficacy on selfregulation and performance among junior and senior high-school age students. International Journal of Behavioral Development, 14(2), 153-164.

Çelik, İ. (2014). Ortaokul ögrrencilerinin öz güven düzeyinin bazı değişkenler açısından değerlendirilmesi: Afyonkarahisar Örneği. Yüksek lisans tezi, Türk Hava Kurumu Üniversitesi, Sosyal Bilimler Enstitüsü, Ankara.

Çelik, Y. ve Onay, İ. (2014). 6. sınıf öğrencilerinin bilimsel tutumları ve öz güvenleri arasındaki ilişkinin çeşitli değişkenlere göre incelenmesi. Asya Öğretim Dergisi, 2(2), 38-51.

Çelikel-Çam, F. ve Erkorkmaz, Ü. (2008). Üniversite öğrencilerinde depresif belirtiler ve umutsuzluk düzeyleri ile etkili etmenler. Nöropsikiyatri Arşivi, 45, 122-129.

Demirel, M. (2013). Investigating guilt and shame situations of secondary school students according to participation in sport activities and different variables. International Journal of Academic Research, 5(2), 259-263.

Eryılmaz, A. (2011). Ergen öznel iyi oluşu ile olumlu gelecek beklentisi arasındaki ilişkinin incelenmesi. Düşünen Adam Psikiyatri ve Nörolojik Bilimler Dergisi, 24, 209-215.

Esentaş, M., Işıkgöz E., Doğan, P. K. ve Şahin, H. M. (2017). Gençlik kampı kadın lider adaylarının öz güven düzeyleri. Kastamonu Eğitim Dergisi, 25(1), 315-328.

Fraenkel, J. R., Wallen, N. E., \& Hyun, H. H. (2012). How to design and evaluate research in education. New York: McGraw-Hill Education.

Göknar, Ö. (2010). Öz güven kazanmak (2. Baskı). Ankara: Arkadaş Yayınevi.

Gönener, A., Öztürk, A. ve Y1lmaz, O. (2017). Kocaeli üniversitesi spor bilimleri fakültesi öğrencilerinin mental (psikolojik) iyi olma düzeylerinin mutluluk düzeylerine etkisi. Sportif Bakış: Spor ve Eğitim Bilimleri Dergisi, 4(1), 44-55.

Guarino A., De Pascalis V. \& Di Chiacchio, C. (1999). Breast cancer prevention, time perspective, and trait anxiety. Unpublished Manuscript, University of Rome.

Güleri, M. (1998). Üniversiteli ve işçi gençliğin gelecek beklentileri ve kötümserlikiyimserlik düzeyleri. Kriz Dergisi, 6(1), 55-66.

Günalp, A. (2007). Farklı anne baba tutumlarının okulöncesi eğitim çă̆ındaki çocukların öz güven duygusunun gelişimine etkisi. Yüksek Lisans Tezi, Selçuk Üniversitesi, Sosyal Bilimler Enstitüsü, Konya.

Haring, M.J., Stock, W.A. \& Okun, M.A. (1984). A research synthesis of gender and social class as correlates of subjective well-being. Human Relations, 37(8), 645-657. 
Kanadıkırık Kılıç, A. ve Kılıç, A. (2013). Ortaöğretim kurumlarındaki öğrencilerin akran zorbalığına maruz kalma düzeyleri ve öz güven arasındaki ilişki, Sakarya Üniversitesi, Eğitim Bilimleri Enstitüsü, VI Ulusal Lisansüstü Eğitim Sempozyumu, 23-30.

Karademir, N. (2015). Fen edebiyat fakültesi coğrafya bölümü öğrencilerinin öz güven algıları. Kahramanmaraş Sütçü İmam Üniversitesi Sosyal Bilimler Dergisi, 12(1), 5477.

Karadeniz, C. ve Özdemir, N., (2006). Sosyal bilgiler öğretmen adaylarının coğrafya alanına ilişkin öz yeterlik inançları (Ondokuz Mayıs Üniversitesi Örneği). Ondokuz Mayıs Üniversitesi Ĕ̌itim Fakültesi Dergisi, 22, 23-30.

Karasar, N. (2010). Bilimsel araştırma yöntemi. Ankara: Nobel Yayınları.

Kazakina E. (1999). Time perspective of older adults: Relationships to attachment style, psychological well-being and psychological distress. Doctoral Dissertation, Columbia University.

Kırşehir İl Milli Eğitim Müdürlüğü (2018). 2019-2023 Stratejik Plan. https://kirsehir.meb.gov.tr/meb_iys_dosyalar/2019_12/18102808_KIRYEHYR_MYL LY_EYYTYM_MUDURLUYU_2019-2023_STRATEJYK_PLANI.pdf adresinden 27.12.2021 tarihinde erişilmiştir.

Kloosterman, P. (1988). Self-confidence and motivation in mathematics. Journal of Educational Psychology, 80(3), 345-351.

Koç, S. ve Gün, N. (2007). Özsaygl: Öncelikler listende kaçıncı sıradasın? (3.baskı). İstanbul: Kuraldışı Yayıncılık.

Koçak, O. ve Çepni, S. (2017). Üniversite öğrencilerinin çalışma hayatına dair beklentilerinin değerlendirilmesi: Yalova Üniversitesi öğrencileri örneği. Trakya Üniversitesi İktisadi ve İdari Bilimler Fakültesi Dergisi, 6(1), 241.

Kutlu, E. B. (2001). İcilik etkinliklerine katılan ve katılmayan ögrrencilerin öz güven düzeylerinin karşılaştırılması. Yüksek Lisans Tezi, Marmara Üniversitesi, Eğitim Bilimleri Enstitüsü, İstanbul.

Lackovic-Grgin, K. \& Dekovic, M. (1990). The contribution of significant others to adolescents’ self- esteem. Adolescence, 25(100), 839-846.

Lane, A. M., Hall, R. \& Lane, J. (2004). Self efficacy and statistics performance among sport studies students. Teaching in Higher Education, 9(4),435-448.

Lindenfield, G. (2004). Kendine güvenen çocuk yetiştirme (Çev. Gülder Tümer). İstanbul: Hyb Yayıncilik. 
Lipingh, C. (2000). A research on university students' development of self-confidence. Department of Psychology, East China Normal University, Shanghai.

Markus, H. \& Nurius, P. (1986). Possible selves. American Psychologist, 41, 954-969.

Mischel, W., Cantor, N. \& Feldman, S. (1996). Principles of self-regulation: The nature of willpower and self-control. In E. T. Higgins \& A. W. Kruglanski (Eds.), Social psychology: handbook of basic principles (pp. 329-360). New York: Guilford Press.

Nurmi, J. E. (1991). How do adolescents see their future? A review of the development of futureorientation and planning. Developmental Review, 2, 1-59.

Owens, T. J. (2001). Extending self-esteem theory and research. Cambridge: Cambridge University Press.

Özbey, Ç. (2004). Çocuk sorunlarına yapıcı çözümler. İstanbul: İnkılap Kitabevi.

Öztürk, N. (2017). Üniversite öğrencilerinin algıladıkları aile iklimi ve anne-babaya bağlanma biçimleri ile öz güven düzeyleri arasındaki ilişkinin incelenmesi. The Journal of International Lingual, Social and Educational Sciences, 3(1), 9-22.

Pajares, F. (1996). Self-efficacy beliefs in academic settings. Review of Educational Research, 66(4), 543-578.

Patır Erkek, N. (2016). Yatılı ve gündüzlü eğitim alan ortaöğretim öğrencilerinin şiddet eğilimleri ile öz güvenleri arasındaki ilişkinin incelenmesi. Yüksek lisans tezi, Gazi Üniversitesi, Eğitim Bilimleri Enstitüsü, Ankara.

Pervin, L. A. \& John, O. P. (2001). Personality, theory and research (8 ${ }^{\text {th }}$ Edition). USA: John Wiley \& Sons, Inc.

Santrock, J. W. (2014). Ergenlik-adolescence. (On dördüncü baskl). Ankara: Nobel Akademi.

Sarıçam, H. ve Güven, M. (2012). Öz güven ve dini tutum. The Journal of Academic Social Science Studies, 5(7), 573-586.

Seligman, M. E. P. (1991). Learned optimism. New York: Knopf.

Slutzky, C. B., \& Simpkins, S. D. (2009). The link between children's sport participation and self-esteem: Exploring the mediating role of sport self-concept. Psychology of Sport and Exercise, 10(3), 381-389.

Snyder, C. R. (2000). Genesis: The birth and growth of hope. In C. R. Snyder (Ed.). Handbook of hope: Theory, measures and applications. San Diego: Academic Press.

Soner, O. (2000). Aile uyumu, öğrenci öz güveni ve akademik başarı arasındaki ilişkiler. M. ̈. Atatürk Eğitim Fakültesi Eğitim Bilimleri Dergisi, 12, 249-260. 
Süpçeler, B. (2016). Ergenlik döneminde algllanan sosyal destek ile yaşam doyumu ve öz güven ilişkisi. Yüksek Lisans Tezi, Yakın Doğu Üniversitesi, Eğitim Bilimleri Enstitüsü, Lefkoşe.

Şar, A., Avcu, R. \& Işıklar, A. (2010). Analyzing undergraduate students’ self confidence levels in terms of some variables. Procedia Social and Behavioral Sciences, 5, 12051210.

Şimşek, H. (2012). Güneydoğu Anadolu Bölgesindeki lise öğrencilerinin gelecek beklentileri ve gelecek beklentilerini etkileyen faktörler. Kuramsal Ĕgitimbilim Dergisi, 5(1), 93109.

Tatar, M. (2005). Öğretmen beklentisi. Yüzüncü Yıl Üniversitesi Elektronik Eğitim Fakültesi Dergisi, 2(2), 1-19.

Taylor, S. E. \& Brown, J. D. (1988). Illusion and well-being: A social psychological perspective on mental health. Psychological Bulletin, 10(3), 193-210.

Tuncer, M. (2011). Yükseköğretim gençliğinin gelecek beklentileri üzerine bir araştırma. Turkish Studies 6(2), 935-948.

Türk Dil Kurumu. (2011). Türk Dil Kurumu sözlüğ̈̈̈. http://www.tdk.gov.tr adresinden erişilmiştir.

Uluçay, T., Özpolat, A.R., İşgör, İ.Y. ve Taşkesen, O. (2014). Lise öğrencilerinin gelecek beklentileri üzerine bir araştırma. Education Sciences, 9(2), 234-247.

Zorba, E. (2012). Herkes için yaşam boyu spor. Ankara: Neyir Yayınları.

\section{Summary}

\section{Problem Statement}

Future expectation points to an individual's self-confidence to some extent. According to Bandura (1997), self-confidence is an individual's judgment of feeling valuable. In other words, it is the individual's confidence in his own abilities, power, and decisions. Selfconfidence provides the person with the belief and confidence that he can achieve a certain job, and thus he can establish control and dominance over his own world (Göknar, 2010). Self-confidence, which is the ability to cope with the problems encountered in life, is an acquired feeling, just like future expectations. Strong positive expectation is the basis of selfconfidence. Because the excess of negative thoughts on a subject reduces the ability to do business on that subject. In other words, success and self-confidence affect each other in 
direct proportion (Lindenfield, 2004). Self-confidence is accepted as one of the important variables affecting the academic performance of students (Lane, Hall \& Lane 2004). There is a positive relationship between self-confidence, motivation, and success. Like many skills, low self-confidence reduces success, while high self-confidence increases success. On the other hand, individuals with high self-confidence are more successful in solving the problems they encounter (Owens, 2001). In existing literature, there are numerous studies in the literature on students' future expectations. However, there is no study to figure out the relationship between self-confidence and future expectations. For this reason, it is important to determine the relationship between students' self-confidence and their future expectations.

\section{Purpose of the Study}

The aim of this study is to determine the relationship between the students' self-confidence levels and their future expectations. This research was carried out in order to determine the relationship between the expectations and self-confidences of high school students in Kırşehir.

For this purpose, the research questions in the study are:

1. Is there a significant difference between high school students' self-confidence and future expectations by gender?

2. Is there a significant difference between high school students' self-confidence and future expectations according to the type of school they attend?

3. Is there a significant difference between high school students' self-confidence and future expectations according to their mother's educational level?

4. Is there a significant difference between high school students' school satisfaction and self-confidence and future expectations?

5. Is there a meaningful difference between high school students' academic achievement and self-confidence and future expectations?

6. Is there a significant difference between the socio-economic level of the families of high school students and their self-confidence and future expectations?

\section{Method}

In this research, relational survey model was used. The data of the descriptive study was collected quantitatively. The sample of the study was consisted of 303 students who were randomly selected from 11th grade high school students. The data of the study were obtained 
by employing two scales. Both "Future Expectation Scale” developed by Şimşek (2012) and "Self-Confidence Scale” developed by Akın (2007) employed to the same students in one session. While analyzing the data, the Shapiro Wilk test was tested for both scales to determine whether the data were normally distributed or not, and the data showed normal distribution [Confidence $($ Statistical $=.930 ; \mathrm{p}=.052)$, Future Expectation $($ Statistics $=.993 ; \mathrm{p}$ $=.141)]$.

\section{Findings and Discussions}

In the light of the findings, gender has been found not an important variable in terms of selfconfidence, but the students’ gender and mothers' literacy levels have made a significant difference in the expectation. It has been seen no difference in both self-confidence and future expectation levels according to the type of school, housing and school dropout tendency. It has also been concluded that students with high school satisfaction levels have low selfconfidence and high expectations for the future. There is a significant difference between the students with high academic achievement level and the future expectancy scores of the students who has medium or fairly well achievement. The difference has been found in favour of second group. Moreover, a significant difference was concluded in future expectancy scores in favour of the students whose family income is at the middle level comparing to the families with high income level. In this study, significant and important relationships were found between having positive future expectations and subjective well-being of adolescents. The findings of the literature showed that increase in the level of hope of individuals lead increases in subjective well-being levels as well (Argyle, 2001; Snyder, 2000). Increasing the level of hope of adolescents may have caused them to develop positive expectations for the future. In this study, significant and significant relationships were found between having positive future expectations and subjective well-being of adolescents. The reason for this finding may be the characteristics of people who are turning to the future. When the literature was examined, it was found that future-oriented individuals exhibited positive functionalities, had health check-ups and exhibited less psychopathology (Guarino, Pascalis, Di Chiacchio, 1999; Kazakina, 1999).

Keywords: High School students, future expectation, self-confidence, secondary education 